\title{
4 Health (and Healing)
}

In the deserts of the heart

let the healing fountain start

W.H. Auden

In older societies, not yet decamped to the American way, and as yet non-toxic as a result, the services used to be called, and indeed were, professions. In such contexts, personal services tended to enjoy a special social climate of warmth, responsibility, caring, and humor as, say, exemplified in the two-sided badinage existing between, perhaps, a favorite barber and a choice client. As a child, on a visit to the interior of India, in a somewhat remote village, I recall some of that all but forgotten élan of a world all but evaporated. In that village, which may not have been atypical at all for the time, one didn't go to the barber; he, in a riot of fanfare and gay costumery, came to you. I had to sit under a (proverbially) spreading banyan tree, mounted on a stool somewhat precariously perched on a rock, as the great man, with an assistant besides him, paused to refresh himself with a cigarette and the accompanying chewing of grounded betel nuts, a mild intoxicant. He looked at me with much amusement, noting my look of alarm (even then, I wasn't fond of hair-cuts), and started a freewheeling investigation into my persona; who was I, what was my name, where and when was I born, did I go to school, who were my favorite movie stars, did I know I looked like about eighteen of them (including a female star!), and so on. Within minutes he had cracked my reserve, dispelled my fears, and had me laughing at jokes that seemed only on the borderline of good taste to a nine year old; and throughout the clipping, the prattle continued, together with advice on how I should strengthen my hair, my bones, my character, and my sexual life to come. I remember now the complete horror, for the haircut was terrible, when I finally looked into a mirror (unavailable to me during the cut), after he had left; but, nevertheless, I remembered the man, his personage, his great effort to turn a humble service into a great vocation, his anxiety to make me feel comfortable, his genuine desire to keep me cheerful, involved, and comfortable, throughout the interaction. He could have been a consultant to many a public relations firm, although he would probably have failed them for being an unconscious artist, without any detachable artifice that could be traded effectively.

It was not dissimilar when I had to, many years later, visit a doctor in Cairo; the complaint was a trivial one, as far as I was concerned - a dry, sore throat that tourists often pick up from overstaying in the Egyptian desert, in disregard of the brutal Middle-Eastern sun. It was a relaxed few minutes before the subject of my complaint was broached; instead, he talked to me about medicine, the challenge of being a doctor, the joy of helping in the healing of suffering; he asked of me of my interests, of my work, of my opinion of Egyptian society, culture, and politics. By the time he was examining my throat, unhurriedly, we were like two old friends settled comfort- 
ably into a genial chit-chat, offering, and receiving, reassurance about each other's tastes, preferences, and life choices. I think now I must have been cured long before the administration of the mild antibodies he had prescribed. He had viewed me as a whole person, had received me as a friend, as a coeval, and not as a clumsy foreigner, ill at ease with cultural cues and social practices; we had met, and parted, as two serious human beings, one of whom happened accidentally to be in a position to render assistance to the other, with no condescension, no effort to patronize, no show of uppity professional elitism, no vanity, or self-consciousness, in the slightest. Here was a man who took his Hippocratic oath seriously, but without pretension. A professional, who performed his services correctly, conscientiously, and without the slightest trace of conceit. A human being, first; but also a doctor - and a professional.

I said professional advisedly, for the magic of our society is that few of the oldstyle professionals see themselves that way; not professionals any more, with a venerable tradition shaping their customary practices that are predictable, identifiable, and accountable to the community - but businessmen, with attitudes shaped by the changing nature of the market-place, accountable only to the barren laws of supply and demand, and the accompanying calculus of greed, outside of the force of social sanctions represented only in the last recourse of malpractice suits. The profession is then quickly transmuted into a business, with all that entrepreneurialism makes possible for producer and consumer alike. Medicine and health services are amongst the biggest businesses (Senator Ted Kennedy once described it as the fastest growing failing business in America) in the U.S., ahead even of defense and armaments (back in 2002, two years into the millennium, we spent an incredible $\$ 1.5$ trillion on healthrelated expenditures, constituting about $15 \%$ of the GDP) with the new, remote, entrepreneur-doctor, closely affianced to the pharmaceutical industry, inaugurating the new golfing, philandering, phlegmatic culture hero (if the soaps are to be believed) of our times. Nostalgia buffs may dust off their microfiches to recall the old, archaic, antiquated notion of providing health care; care and caring, the vocation to serve, to heal, to soothe the sufferings of the many, so reminiscent of images of Florence Nightingale and Mother Teresa, are all now so much history, and memorabilia. Health is a growth industry, as the professionals themselves describe it, and the doctor is the budding industrialist, tending, in proprietary fashion, not the sick and the ailing, but his market, his revenues, his empire, his/her consumers, his constituency.

The process of a virtual deregulation, and privatization, and industrification, of the practice of medicine was begun in earnest perhaps in the seventies (private insurance, e.g., started undercutting non-profit insurance, at about this time) and is a completed fact today. As doctor's incomes raced ahead of other professionals (not yet turned businessmen), so did their self-images, their egos, their aloofness, their distance from their patients, their tendency to play god, and their assumption of perfect infallibility vis a vis their social inferiors who had the galling presumption only to be ill and in want - who had never ridden, for the most part, on motorized golf carts on the fairways, and the standard, de rigeur, Porsches on the highway home. Hip- 
pocrates would likely swoon several times in his grave if he could glimpse the average American medical practitioner at work; and, possibly, at play.

All that capital-intensive, hi-tech industrification - in 2010, we spent \$2.6 trillion on health related expenditures, constituting about $17 \%$ of the GDP, and yet to what effect?

Here's some non-trivial data: Let's do a rapid taste-test : take the USA in relation to France, Cuba, and Israel, starting with 1997 data.

Taking health care expenditures as Percentage of GDP we have the following:

USA: $13.7 \%$ France: 9.8\% Cuba 6.3\% and Israel 8.2\%.

Taking health care expenditures per capita we have:

USA $\$ 3,734$, France $\$ 2,125$, Cuba $\$ 109$, Israel $\$ 1,402$.

And here's how it looked in 2001 figures:

For the USA: total health expenditure as per cent of GDP (2001): 13.9; total health expenditure per capita (Intl \$, 2001): 4,887.

For France: total health expenditure as per cent of GDP (2001): 9.6; total health expenditure per capita (Intl \$, 2001): 2,567.

For Cuba: total health expenditure as per cent of GDP (2001): 7.2; total health expenditure per capita (Intl \$, 2001): 229.

For Israel: total health expenditure as per cent of GDP (2001), 8.7; total health expenditure per capita (Intl \$, 2001): 1,839.

In 2010, the US topped the world with per capita expenditures on health of $\$ 8223$, at $17.6 \%$ of GDP; in 2012, this rose to $\$ 2.8$ trillion, at $\$ 9000$ per head, and at $18 \%$ of GDP.

For France, comparable figures were: $\$ 3978$, at $11.6 \%$

Israel, \$2071, at 7.5\%

Cuba, $\$ 1965$, at $2.6 \%$

Sure, we continue to 'lead' the world (as we so love to) in spending, but what of the actual desserts?

In terms of Health System Performance Ranking, here's the Score-card:

USA, at 37; France, 1; Cuba, 39; Israel, 28.

In terms of overall levels of health:

USA, 72; France, 4; Cuba, 36; Israel, 40.

Or, we can look at other indices such as life expectancy, infant mortality, and the number of doctors, nurses, dentists, and hospital beds per capita.

Here's the data: life expectancy in years (2004):

France, Rank 16, 79.44 years ; Israel, Rank 21, 79.17 years; United States, Rank 48, 77.43 years ;Cuba, Rank 53, 77.04 years.

Or, take infant mortality as of 2006:

Israel, Rank 20, 4.7; United States, Rank 33, 6.3; Cuba, Rank 28, 5.1 France, Rank 12, 4.20 .

Or, take sheer numbers of qualified health personnel- here, the number of doctors, nurses, and dentists: 


\begin{tabular}{llllllll}
\hline \multicolumn{7}{l}{ Rate per 100,000 population / Year } \\
\hline & \multicolumn{2}{l}{ Physicians } & \multicolumn{2}{l}{ Nurses } & \multicolumn{2}{l}{ Dentists } \\
\hline United States & 279 & 1995 & 972 & 1996 & 59.8 & 1996 \\
\hline Israel & 385 & 1998 & 613 & 1998 & 116 & 1998 \\
\hline France & 303 & 1997 & 497 & 1996 & 67.8 & 1996 \\
\hline Cuba & 530.4 & 1997 & 677.6 & 1997 & 84.5 & 1997 \\
\hline
\end{tabular}

Or, hospital beds per 1000 people:

\begin{tabular}{llll}
\hline USA & France & Cuba & Israel \\
\hline 3.5 & 8.1 & 4.6 & 6.3 \\
\hline
\end{tabular}

Or, perhaps we might examine the Uninsured:

USA: 45 million, and counting - whilst France, Cuba and Israel have Universal Health Care.

Or, take obesity, a runaway epidemic in the US(obesity is defined as having a Body Mass Index score of 30 or more):

In 2000, 19.8 percent of the US adult population (aged 20 and over) was obese, an increase of 61 percent since 1991. And current figures show that about 30 percent - or 59 million adults - are obese. 15 percent of children age 6 to 19 are overweight, about triple the proportion 20 years ago.

We are, sadly, not quite the world leaders we think we are: except, perhaps, negatively.

I had been only a year in New York when television presented us with the itcan-only-happen-in-America story of hospitals, physicians, and health administration. A tourist on a brief visit to New York had been mugged, and stabbed in the back; miraculously, a passer-by, an ordinary, improvident, New Yorker, bundled him into a taxi (only the unincorporated ragged-trousered seem capable of genuine philanthropy), with the knife still stuck in his ribs, and rushed him to the nearest private hospital. Astonishingly, if you hadn't foreknowledge of the 'system' that devours us all in this mother of market-societies, the hospital refused to attend to the bleeding victim, for he had no insurance, and possibly even lacked the funds to pay; incredibly, the poor man, knife in back and all, had to be bundled into a taxi again and rushed off, by his unknown benefactor, to some other asylum, where civilization could be redeemed, and human values valued. I do not know what eventually happened to the unfortunate tourist, for the media did not take us any further into the 'story'; but what really capped the evening's thundering barbarism was the subsequent interview with the physician-administrator who not only stood by the hospital decision, but went to obscene lengths to defend it, boldly and unrepentingly, in front of tv cameras and millions of viewers. It was just another evening in New York's cumulating catalogue 
of petty sins against human-ness; and this was long before Reagan and Thatcher had made such retrograde attitudes actually hip and fashionable even amongst the East Coast, generally liberal, intelligentsia. Today, this rabid shuffling-off of all caring is a virtual American patent.

Indeed, revolting, unethical behavior in the profession is so common as to escape attention altogether. I have sat in the emergency rooms of many a major research hospital, only to see the studied, cool, indifference with which patients, in critical emergencies, are treated by rather well-paid, and presumably trained, hospital staff. I observed a black man (in America we need to specify skin color to get a first approach to issues) once lurch up to the counter in mortal pains, only to have to wait a full three minutes before the reigning queen of the emergency counter, busy exchanging wisecracks with a gum-chewing doctor on duty, at the inside end of the counter, finally deigned to notice him: contemptuously then, and with ill-grace. By then, the poor man had collapsed, and had to be taken in on a stretcher to encounter god knows what dereliction of duty on the inside of that commercial enterprise. I hope, for his sake, he had insurance.

The doctor, the nurse and the assistant, after all, are only the microcosm of the health profession; behind them, stands the grey eminence of the American Medical Association, one of the few genuine monopolies in the US business world - here, the giant business is self-regulated to keep incomes high, the supply of physicians low, and the competition out. Here, the high priests of allopathy meet to rule out all threats to industry; i.e. alternative forms of medicine, of healing, of treatments. Remember when Acupuncture wasn't kosher, mocked and derided as a piece of rank oriental mysticism, until it was all seen graphically on tv, beamed from a Chinese hospital in Peking? Then there's homeopathy, still illegal in many states. And, of course, Chiropractic; I developed a backache once that wouldn't go away, and went to a back surgeon who couldn't find anything wrong, in two visits, but was quite willing to go in for 'exploratory surgery', anyway. Fortunately, I went to a Chiropractor who set the matter right with short manipulations, in only two brief sittings of fifteen minutes each. I went back to the AMA specialist to review matters; he wouldn't hear of it. It must have been all in my mind, he said. There was probably nothing wrong with my back, clinically. He would stake his six-figure income on it.

Father knows best, he was telling me, if not in as many words; he was the doctor and it follows that a doctor knows more about illness and disease than any patient who, poor, dumb slob, only has his own symptoms, his own sufferings, to learn from. If he, the physician, didn't know it, it didn't exist - no matter what I said, felt, or did. Herein is the secret of oppression, the covert tyranny of Science: it requires not the validation of others, not even the corroboration, and oft-times not even the consent, of the very subjects upon whom the Science is to be practiced. There are all kinds of analogs of this posture of omniscience; try telling a Freudian pschoanalyst you've never had secret feelings for your mother - your very denial of it becomes a form of resistance to the truth of Oedipal behaviors. Sigmund knows best. This can be perfectly harmless if 
scientist and layperson are on par in terms of the logic of power; but it is fraught with sinister danger when the scientist is able to recruit state power to impose his/her construction upon the layperson. Just think of the hapless inmates of psychiatric wards in Adolf's Germany and Stalin's Russia; but, truly, is America any different?

American medicine - as it is practiced and delivered at the grass roots, is not, strange as it may seem, fundamentally, into either healing or curing; basically, it is a specialized system of symptom-suppression and symptomatic relief (the band-aid could be its immediate, and eloquent, symbol; for that sort of thing is what they're really good at) that aims at patching people up so they can pick up and carry on, a sort of a running medical complement to this pre-eminently disorder-producing society. The specialization, of which there is enough to make you hurt, is a pure business function; you broke your leg and hurt your hip, and fifty years ago you went to one doctor, who took care of it all, and got you back on your feet. Now you go to three; one looks to below your knees, one above, and the other is a hip expert. You'll pay them all, naturally, and handsomely; and then there's the sub-contractors, the one who photographs you, the one who X-rays you, the one who takes your temperature, and so on; and of course, you'll give blood, in a manner of speaking, to all of them as well. The hospital used to be centered around the patient, with doctors and nurses in attendance; now it's a sprawling establishment centered around administrative offices, heavy equipment, laboratories, and doctors; yeah, there's patients in it too, somewhere, but they usually have to wait outside. The robotization of technique, process, and commercialization is complete; and the old polarity has been reversed - it's a supply-driven business now teeming with 'health administrators', consultants, insurance agents, equipment entrepreneurs, and pharmaceutical salesmen (you should probably be respectful to the latter personnel; chances are they may actually perform the surgical procedures on you, while you're under sedation, just to 'demonstrate' to the doctors a new instrument or a new drug). At the delivery point, it centers on the doctor; further upstream, the administrator; still further, the high-tech medical instrument industry, the AMA, the National Institute of Health (NIH), the Centre for Disease Control (CDC), the FDA, the Federal Government, and so on. Any wonder the average patient gets the third degree, is probed, prodded, pushed, cajoled, marched from door to door, clerk to clerk, robot to robot, lab to lab, cashier to cashier, before the 'service', indifferent as it is, is finally obtained? A trip to the hospital can be as enervating as an afternoon with a gaggle of kids in a children's amusement park, if not quite as much fun. It's a high-tech, high-volume, high-profit, business; and the patient belongs in it about as much as a car buyer in a GM production plant.

Symptom-suppression is enormously profitable, for the pharmaceutical companies that manufacture the pills and palliatives, the doctors who prescribe it, and the hospitals that gorge greedily on escalating patient fees. And, gosh, are there a lot of symptoms to suppress! Over 60,000 brands of drugs are sold in America (compared to only about 8000 in laggard France); aren't we lucky, compared to all those foreigners with their unglamorous, drug-starved, low-tech, health care systems! Small matter, 
then, that a full 60 per cent of that impressive proliferation of drugs, that we so enjoy, were found to be utterly worthless by physicians with a still lingering sense of social responsibility! The World Health Organization, an international, reasonably responsible body, has suggested, further, that when it comes to well-documented drugs for well-documented disorders, the list of necessary medicines is less than 250 ! Less than 250 !; and they sell us 60,000! - are they treating us, or are we treating them?: to megabucks and mega-profits in a mega-growth, mega-industry!

So the funding, private and public continues, and costs escalate wildly (on average at twice the rate of inflation), even though few corresponding social benefits ensue. Life expectancy has not altered dramatically since the health industry explosion of the seventies, nor has Public health improved (the AIDS-infected population, by official definitions, is set at millions, and growing; but where did this mystery disease spring from? One hypothesis, as reported obscurely in the New York Times, years ago, quoting, without comment, a Tass release: a leak from a U.S. Defense department Biological warfare lab! Farfetched? Well the CIA reportedly did test a species of nerve-gas in the New York subways, not so very long ago); how could it, when we refuse to make a dent in poverty, in unemployment, in homelessness? Nor, despite the enormous drain on public revenues, have amply-funded research programs come up with any inspiring cures for the near-chronic diseases of an industrial civilization, stemming from poisoned ecospheres, stressful work and living environs, and additive-rich foods: over 70 per cent of all deaths continue to be from cancer, heart, and respiratory illness, and accidents (lately, suicides have overtaken accidents). The implicit refusal by the AMA monopoly to allow alternative - i.e. competitive - healing systems (usually effected through refusal of insurance) only aggravates the sufferings of the gravely ill, who now have to spend even more to reach and retain alternative therapies far from the beaten track of authorized, allopathic, all-American medicine, playing dog-in-the-manger with the lives of the seriously ill.

I knew a Chinese traditional medicine practitioner, recently arrived from the mainland, who was anxious to obtain funding for a pilot project involving AIDS patients who are to be administered Chinese herbal medicines, under her care, that she was certain could demonstrate the potential for a decisive reversal of AIDS symptoms, resting in Chinese treatments. It seemed for a while that fortune was about to favor her, for she managed to display her skills in the treatment of an American physician who was also an AIDS victim; in just over a year of treatment, the patient had gained weight and self-confidence, while his immune system showed definite signs of recovery: together, sharing a common excitement, the Chinese doctor and the American physician/patient tried to get the funding for a large scale, experimental study. After three years of desperate efforts, the Chinese doctor threw in the towel: a combination of government sloth, and AMA intransigence, kept them tied down to square one.

You can't beat the medical establishment, at politics at any rate; but the Chinese doctor beat them at healing almost every day. I know because I have sat there watching these routine 'miracles', wondering how we, in our cosmic blindness and super- 
nal cupidity, could afford not to learn from the Chinese. One day, a Thai woman was brought into her clinic, the victim of an automobile accident; she was paralyzed, and the hospital had told her there seemed little hope of recovery, but they were ready (again) to do 'exploratory surgery' of the back. The Thai lady neither had faith in these doctors, nor could she afford to make such payments as surgery would have entailed; so, she came to check out one of the few Acupuncture clinics in town, brought in on a stretcher by her distraught family. As I watched, the Chinese doctor looked her over calmly, had her placed on one of the clinic beds, put needles in various parts of her body, and came out to chat with me, while the Thai lady lay there, for a good twenty minutes. Then she rose and went back into the examination room and took out all the needles, while the patient's family and I watched anxiously, quite mystified by the procedures. Then came the astounding part: 'Get up', she said to the Thai woman, 'get up and walk'; the patient looked shocked, as did we all, wondering. Then came the miracle; our doctor yanked the patient by the hand, and, before our wonderstruck eyes, the poor, paralyzed, little woman, brought in on a stretcher, no less, but a half an hour ago, got to her feet and slowly walked out of the room. Her attending family cried; so did the patient, and so did I - pretty nearly. And if you're reading this, Dr. Li, may your tribe increase, because you are a miracle worker (but that's just the problem; not only does she perform miracles, she is expected to - patients coming to her only as the last resort, at advanced stages of apparently incurable illnesses), even if an ignorant, prejudiced, corrupt medical establishment will not give you your due.

Like all ultra-capitalist, cutting edge, businesses, the American medical industry thrives on the technology it aggressively fetishizes, as do the rest of us space-age, moon-walking, citizenry. After all, we are the Flash Gordon gang, the Star-Trek fans, the gadget nuts, the video-arcade zombies, and the glassy-eyed, computer buffs, in our ordinary, unsplendid, lives; and we're sold the moment we see even larger gadgets, bigger video-screens and faster super-computers in our surreal, space-age, medical centers. Hospitals and doctors vie with each other to acquire and display their stateof-the-art technological marvels, the color video monitors, the laser guided instruments, the digital displays, and the host of beeping, blipping, humming, ringing, and tapping paraphernalia, that elevate the doctor's clinic above the less show-stopping, less capitalized, dowdy enterprises in the service industry such as accountants, tax preparers, masseurs, therapists, and so on. The ubiquitous technology, spuriously, reinforces our image of the physician as Science-Incarnate, as the subtle Diagnostician of Tetrahydrons and DNA, as the daringly pioneering researcher into the inscrutable mysteries of human physiology (the fact that all the glittering high-tech gadgetry has to be demystified, i.e. intellectually down-sized, for the doctor by a salesman with a high school diploma is, of course, less well known). The technology is not necessarily productive, useful, or even necessary, in some cases (aside from being positively dangerous in some instances where large doses of radiation are emitted); but, in virtually all cases, it jacks up costs, swells doctors' coffers, and raises patient expenditures, reliably. 
My ex-wife comes from a family with a history of chronic stomach trouble; suspecting herself to be genetically prone, and recognizing some painful symptoms years ago, she went to a specialist physician who, after several tests (tests even more painful, and uncomfortable, than her symptoms), determined that she had ulcerative colitis, only a step short of colon cancer. There was little hope held out to her (there is, apparently, no 'cure' in the AMA book for the condition); but she was given a bunch of pills, stomach sedatives/tranquillizers, etc., that she was asked to take for the rest of her life. When I heard about it, it seemed to stand up to the patented AMA formula: we can't cure it, but we'll give you all manner of pills - so you can keep coming back to us forever for prescriptions - that'll kill off most of the symptoms, or most of the patient, whichever comes first. Now go home, and be happy you can count on such sophisticated therapies being available to you so very readily in your own neighborhood. I watched her suffer through her continuing pain, in spite of the tablets, capsules, and caplets, which might as well have been sugar pills, for all their effectiveness. And I remembered my own childhood ailments, growing up in India, and the kindly, neighborhood homeopath, who dispensed free medicine, to all and sundry, every Sunday morning from 9 to 12; a devout religious man, and a humanist, he performed this as a public service - 'to relieve the sufferings of humanity', as he put it matter-of-factly.

I asked my ex-wife if she'd be willing to go to India to try homeopathy; at first, she was resistant, sharing the ideology of skepticism toward all things non-American, that we're all so good at; but, she was in acute physical agony, and ready to try anything. So we went It was educational for me to watch the homeopath in action; there was no talk of fees, and payment schedules (he didn't even ask me for my work address and phone, in case I needed to be turned over to Collections, as with my friendly, wisecrack-laden doctor in America). He questioned my wife intently about every thought, every feeling she'd ever had about her illness; he asked after her relationships, her feelings of contentment, and resentment, towards life, parents, husband, friends; he asked of her assessment of herself as an individual, her outlook towards the world, her hopes, dreams, and inclinations. And, as she spoke, trance-like, he took copious notes trying not to miss anything she said, attentively, urgently; it took almost three hours for the diagnostic interview to be completed. There was no bloodletting, no X-rays, no painful insertions or exertions; and, at the end he asked us to leave so he could study her case over 'for a few days'. When we returned, he had a bottle of already compounded medicine, thirty pills in all that my wife was to take for the next three months. He said no fees were needed; we could pay, if we chose to, 'after she was cured'.

In three months, she was cured; and this was not symptom-suppression; it was a total cure. Just to make sure, she went to a hospital to be checked out. After many painful tests, the verdict was clear: she had not one symptom left of ulcerative colitis. The 'incurable' disease had vanished, like it was never there, like it had never been. All this was a form of catharsis for my wife; years later, we went back to India to thank this magician personally, and pay for the invaluable, priceless, service, performed 
humbly and modestly by a little Indian homeopathic doctor whose only investment in high-tech for his clinic, for his patients, was a table-fan with a six-inch blade span. I think Hippocrates would have approved (but just think what his American counterparts could have taught him about entrepreneurship!; and, if you're still not convinced doctors in America are privateer/entrepreneurs, here's a quick Quiz: why do you think more babies are born via caesarean section - an amazing 22 per cent of all births in 1992, and rising to 32.8\% in 2011 - in America, than in the natural way? Clue: it is not because all would-be mothers prefer it that way).

It is not just that alternative medicine has cures for things the AMA couldn't even get to defining the condition of; it is the whole social and medical philosophy underlying benign, patient oriented, non-commercial, holistic medicine. Our homeopath was not treating the illness, or the condition, or the affliction (in that coldly precise, wish-I-were-golfing-instead way, that the contemporary allopath handles matters) but the whole living, thinking, feeling, sensing, suffering, human being afflicted with it. Here there are no radical separations, no dualisms, (no body/mind distinctions, for instance that plague Cartesian allopathy), no distancing, between patient and illness, between patient and doctor; the symptom is a red light that is educating the homeopath as to the nature of the problem; he does not dare to shut off the body's vital communicative device - indeed, he lets it speak clearer, louder, so as to listen, diagnose, and help the body heal itself. And yet, ninety percent of the time we rush off to the drugstore to buy pills that turn the signals off, and shut off the flashing lights, doing grievous damage to our bodies, and their underlying physiological processes, while a colossally powerful medical machine, armed with the secure stature of infallible 'Science', endorses our behavior, sanctions it, encourages it, with all its resources: how else, otherwise, could it live off of it as handsomely as it does? Have you seen a doctor drive by, lately?

The technology fetish, as I said, reinforces the science fetish; let's face it, liberal or conservative, oft-time even radicals, share the ideological conditioning that makes of Science the most powerful establishment of our times. In the seventeenth century, it was the Church, backed by the State, that commanded virtually universal respect; today, we have transferred this idolatry to Science (again, with the backing of the State). Science gives us commandments today much as the medieval church did: thou shalt be Inoculated, thou shalt believe in evolution, thou shalt be tested for AIDS, and so on. Interestingly, Science is not required to prove its prejudices, just to state them and it is enough, it is mandated; the dumbly loyal state will enforce its decrees. In many states homeopaths cannot practice; the allopathic mafia have prevailed over government. Is this because the AMA conducted open, scientific, research into the practices of homeopathy to determine whether it is right, or wrong, or deluded(for the interested, the British Journal Lancet reported quite favorable results for homeopathy)? No: it is not necessary - the a priori pronouncements of the Scientific Elite require no testing, no scrutiny by the disinterested, no review by democratic bodies. Scientists are right for being scientists: no further validation, or proof, or independent 
confirmation, is necessary. The experts have spoken; and experts are to the scientific estate what the anointed priesthood was to the medieval church.

And we all know the power of the experts; they are wheeled in and out by the media whenever a point is to be made, and public opinion needs to be shaped, directed, altered, or fixed; and few of us even remotely suspect that the cult of expertise might be a fraud, that Science is a material, power-hungry, resource-grabbing, entity like any other lobby, pressure group, or vested interest. And yet we should know better; haven't we seen economists argue both sides of a policy? Haven't we seen doctors, pathologists, epidemiologists, and medical researchers, take both sides of the smoking controversy? Don't we know yet that experts can be bought, cajoled, gagged, influenced, prejudiced, exploited, at will? Do we still need to be de-briefed to understand that scientists, experts, surgeons, whatever, are ultimately only people, heir to all the weaknesses the human flesh is prone to? Science is not required to compete, anymore, with other sources of belief; the AMA is the law of the land - it need not prove itself. And so the medical establishment becomes yet another selfserving, sanctimonious, self-righteous, association of the few, with a common material interest to defend, protect, cherish and nurture - against all comers (would you think the findings of medical research are a common human resource, available to all? - the NIH (National Institute of Health) has just announced it will patent, yes, patent, human genes as they are discovered, guaranteeing monopoly, and monopoly gains (Author's Note: this, by now, in 2015, is wholly passé).

We need to rethink our underlying philosophies: most of us, in the twentieth century, especially those living in the West, tend to think that almost all 'modern medicine' is our own creation, the achievement of our Brave New Scientists, inventors, and medical whiz-kids. It is a prevalent, dominant, myth - suggesting that this is the best of all possible worlds, because we are so much better off, smarter, healthier, better fed, better nursed, etc., than the 'primitives' we have left behind, either in our own European history, or in the ancient worlds of the Orient. In giant part, this is an outright fantasy; modern western medicine has plundered - and built upon - the long heritage of existing medical knowledge, compiled patiently, and painstakingly, by our putatively savage ancestors. The medicinal plants and herbs discovered by our forebears, including Native Americans, Africans, Indians, and Chinese, are at the chemical bases of all our subsequent discoveries, innovations, adaptations. All this is perfectly natural: traditions borrow from each other, and enhance mutual learning. Diffusion is the Mother of further Civilization. But, we have reached a critical juncture in America, where the 'two-way' path to learning has been all but wiped out; we feel we have nothing left to learn from the primitives, the homeopaths, the chiropractors, the natural medicine people, the faith healers, and so forth. Worse, we are all but ready to annihilate alternative traditions, out of a savvy business interest alone, thereby destroying forever the great, cumulative, diversity of the ages, the common heritage of humankind, that has produced, and nurtured, human knowledge for thousands of years. We have the means, the power, to destroy these long-lived traditional alterna- 
tives today; they, the 'Others', lack the power, the material resources, to resist. As in politics, and in economics - so it is with medicine.

In capitalism, you get capitalist health-care; one system for the rich, another for the poor, a cafeteria approach - you're supposed to get, indeed deserve, what you can pay for. What could be more explicit? The thirty five million or so classified as poor, by official definition, and millions more on the borderline of that dubious 'poverty line', have virtually no access to regular health care: at least a full 37 million have no coverage at all, a situation (about 32 million of the uninsured are to receive protection under Obama-Care - on the books since 2010, and to be fully operational by 2014 but this is already subject to legal and political challenge) without true parallel in the entire industrialized world. Not that the middle-classes fare a great deal better, although their emergency needs are better covered, so it is the rich who primarily enjoy the benefits of all the high-tech medicine, the expensive specialists, the milliondollar installations, the private care facilities, etc. (we do have a Welfare State, as the conservatives bellyache endlessly, but for the rich, for the corporations: just one example homelessness gnaws visibly at the fat ribs of our capital city, but 56 per cent of Federal Housing subsidies go to the richest fifth of Americans). Residents of rural areas, the elderly, the indigent, and the uninsured, face a permanent crisis in this regard that is nothing short of a national disgrace; at an average of over $\$ 1600$ a day, 3 times the cost compared to other industrialized nations, and rising, how many can survive hospitalization, financially, even if they actually recover from their ailments? It is not that we couldn't remedy these grotesque absurdities; Europe, even so-called 'third world' countries, have minimum national health insurance packages that make us look like subjects of the regime of Ivan the Terrible (New York, one of the richest states in the country, was fighting a recurrence, in epidemic form, of Tuberculosis, Measles and Syphilis, in the nineties, behind many 'third-world' nations), or some other Occidental Satrapy, languishing in the Dark Ages. We could do it; even capitalist Britain (and equally North American Canada) has a National Health Service, so the idea is not that radical - but the powers that be will fight it to the last. We are not Neanderthals for nothing (Bill and Hilary Clinton got enormous flak, early on for their proposed National Health Plan, one of the few, if threadbare, links to genuine social democracy in their respective platforms; of course, like any plan, it had its faults: but, did the vociferous critics have an alternative to the status quo? Similarly, was Obama chastised, during the campaign - and after).

At any rate, the sickness of America is not primarily an issue of human physiology and bio-chemistry, but of serious psycho-social and ecological disorder, malfunction, and displacement. We are profoundly out of touch - and have been for the longest time - with the springs of feeling, the founts of generosity, and the flows of compassion; we are out of touch with ourselves, our societal relations, our linkages with the universe, physical and social. We have generated the very pressures, the cycles, the crises that now threaten to tear down our own beloved constructions, to destroy the lives we have sought to protect, to undo the very planet that nourishes us. 
Bodily cancers, and their causes, are easy enough to observe: most of us eat, drink, and dissipate, wildly beyond the reach of the average citizen of the world (most of our drug use is simply restitutive, correcting for self-inflicted, gross, insensate, abuse); we live in rapacious conflict with each other, with ourselves, and our environment: generating it, reveling in it, seeing fiscal gain in it, living and dying in it. We envy, hate, despise, and abuse each other, race to race, gender to gender, ethnic to ethnic, sect to sect, person to person. Our preferred ideology of unlimited money-making, naked extortionism, and relentless material advancement, can only be ruinous of any kind of social peace, tranquillity, and concord (there are about 700 tranquillizers against stress; of these, just one, Valium, was prescribed over 50 million times a year, on average, to be succeeded, later, by Setraline, Citalopram, and Prozac). We are a world of volcanic tensions ready to erupt, in a burst of dementia, at any time, at home, in a supermarket, in a school, anywhere (to just hint mildly at the grisly reality: in just one calendar year, there were over 200,000 recorded instances of students beating up teachers in the classroom, over 8000 cases of rape in school restrooms, and a 100 murders - all within school-hours; in 2007, 6\% of high school students were estimated as carrying a weapon to school, with $7-10 \%$ of teachers threatened with physical violence by students): the Columbine massacre of 1999, followed by Northern Illinois and Virginia Tech killings later, simply placed it all in national focus. But the cancer of the soul, of the spirit, of the psyche; that is where our most serious maladies lie, rather than in mere bodily prostration, physical mortification, and the inexplicable surrenders of the flesh. The healing needs to commence there, and soon; for we are pretty close to the apocalypse (of purely human design) as it is. 